\title{
Glycolytic glioma cells with active glycogen synthase are sensitive to PTEN and inhibitors of PI3K and gluconeogenesis
}

\author{
Marie E Beckner ${ }^{1}$, Glenn T Gobbel ${ }^{2}$, Roger Abounader ${ }^{3}$, Fatima Burovic ${ }^{2}$, \\ Naomi R Agostino ${ }^{2}$, John Laterra ${ }^{3}$ and Ian F Pollack ${ }^{2}$ \\ ${ }^{1}$ Department of Pathology, University of Pittsburgh School of Medicine, Pittsburgh, PA, USA; ${ }^{2}$ Department \\ of Neurosurgery, University of Pittsburgh School of Medicine, Pittsburgh, PA, USA and ${ }^{3}$ Kennedy Krieger \\ Institute, Johns Hopkins University School of Medicine, Baltimore, MD, USA
}

\begin{abstract}
Increased glycolysis is characteristic of malignancy. Previously, with a mitochondrial inhibitor, we demonstrated that glycolytic ATP production was sufficient to support migration of melanoma cells. Recently, we found that glycolytic enzymes were abundant and some were increased in pseudopodia formed by U87 glioma (astrocytoma) cells. In this study, we examined cell migration, adhesion (a step in migration), and Matrigel invasion of U87 and LN229 glioma cells when their mitochondria were inhibited with sodium azide or limited by $1 \% \mathrm{O}_{2}$. Cell migration, adhesion, and invasion were comparable, with and without mitochondrial inhibition. Upon discovering that glycolysis alone can support glioma cell migration, unique features of glucose metabolism in astrocytic cells were investigated. The ability of astrocytic cells to remove lactate, the inhibitor of glycolysis, via gluconeogenesis and incorporation into glycogen led to consideration of supportive genetic mutations. Loss of phosphatase and tensin homolog (PTEM) releases glycogenesis from constitutive inhibition by glycogen synthase kinase-3 (GSK3). We hypothesize that glycolysis in gliomas can support invasive migration, especially when aided by loss of PTEN's regulation on the phosphatidylinositol-3 kinase (PI3K)/Akt pathway leading to inhibition of GSK3. Migration of PTEN-mutated U87 cells was studied for release of extracellular lactic acid and support by gluconeogenesis, loss of PTEN, and active PI3K. Lactic acid levels plateaued and phosphorylation changes confirmed activation of the PI3K/Akt pathway and glycogen synthase when cells relied only on glycolysis. Glycolytic U87 cell migration and phosphorylation of GSK3 were inhibited by PTEN transfection. Glycolytic migration was also suppressed by inhibiting PI3K and gluconeogenesis with wortmannin and metformin, respectively. These findings confirm that glycolytic glioma cells can migrate invasively and that the loss of PTEN is supportive, with activated glycogenic potential included among the relevant downstream effects.
\end{abstract}

Laboratory Investigation (2005) 85, 1457-1470. doi:10.1038/labinvest.3700355; published online 19 September 2005

Keywords: astrocytoma; gluconeogenesis; glycogenesis; glycolysis; migration; PTEN

Malignant glioma (astrocytoma), the most resistant type of brain tumor to treatment, is characterized by diffuse invasiveness that prevents successful resection. ${ }^{1}$ Earlier studies showed that melanoma cells have the potential to migrate using ATP produced only by glycolysis. ${ }^{2}$ Increased ATP production via glycolysis is required by tumor cells whenever tissue levels of oxygen fall or mitochondrial respiration is defective,,$^{3-5}$ especially during active inva-

Correspondence: Dr ME Beckner, MD, Department of Pathology, University of Pittsburgh School of Medicine, 200 Lothrop Street, PUH, Room A-515, Pittsburgh, PA 15213, USA.

E-mail: becknerme@upmc.edu

Received 7 June 2005; revised 11 August 2005; accepted 12

August 2005; published online 19 September 2005 sion. The resilience of malignant gliomas to anaerobic conditions suggests that their potential for glycolysis is increased. ${ }^{5-7}$ Large amounts of glucose can be transported into glioma cells for glycolysis and increased glucose extraction within the tumors ${ }^{8}$ is accommodated by increased expression of GLUT3 transporters. ${ }^{9-11}$ Maintaining increased levels of hypoxia-inducible factor- $1 \alpha$ (HIF$1 \alpha$ ) is one mechanism that induces glycolytic enzyme expression. ${ }^{12}$

Recently, in proteomic studies of U87 glioma cells that harbor mutations of phosphatase and tensin homolog (PTEN), we showed prominence of all seven enzymes in the distal, energy producing portion of the glycolytic pathway with enhancement in pseudopodia. ${ }^{13}$ Cell protrusion, adhesion, 
deadhesion, and cytoplasmic retraction are steps in the migratory process. Agents that upregulate glycolysis in malignant cells, such as HIF-1 $\alpha$, have already been established as treatment targets in numerous studies. Although using NADH to reduce pyruvate to lactate via lactate dehydrogenase maintains glycolysis by regenerating NAD under anaerobic conditions, the buildup of lactic acid is inhibitory and is usually avoided by rapid release into the bloodstream. Extracellular lactate dehydrogenase to reconvert released lactate back to pyruvate would not be available unless nearby cells were injured. The intracellular removal of lactic acid by conversion to glucose and glycogen is a mechanism of metabolic control that has not been explored in tumors. Anaerobic production of lactic acid requires its conversion to prevent inhibition of glycolysis when cells are disconnected from the vasculature and cannot release their lactic acid into the bloodstream.

Metabolic conversion of lactate in astrocytes led to consideration of a potential role for this process in gliomas. Astrocytic cells are unique in that they use glycolysis to produce lactate to be shuttled into nearby neurons and converted into substrate for oxidative metabolism to augment neuronal energy supplies. ${ }^{14-18}$ Excess astrocytic lactic acid is either removed via the vasculature or temporarily stored by metabolic conversion into glucose and glycogen or into alanine. ${ }^{14,19-21}$ Signal transduction that permits activation of glycogen synthase (GS). ${ }^{22-24}$ aids lactic acid conversion to glycogen in cells with gluconeogenic potential, including astrocytic cells. ${ }^{19,20}$ We hypothesize that when negative control of GS is lost due to mutations in gliomas, conversion of lactate into glucose and glycogen allows glycolysis in malignant cells to exceed normal limits. Intermittent rather than continuous vascular contact during tumor invasion may suffice for cells with intracellular lactate removal. Also, tolerance for hypoxia via gluconeogenesis and glycogenesis may support glycolysis in pseudopodia with oxidative metabolism occurring in another cell region to compensate for the energy debt of gluconeogenesis. Glycogen accumulation would vary due to concurrent glycogenolysis.

Mutational loss of normal inhibitory controls on glycolysis that allows tumor cells to escape a strict reliance on vascular support should promote tumor invasion. Mutations of PTEN that commonly occur in gliomas ${ }^{25-28}$ lead to loss of negative regulation on the phosphatidylinositol-3 kinase (PI3K)/Akt pathway. The resulting deactivation (phosphorylation) of GS kinase-3 (GSK3) permits activation (dephosphorylation) of GS whenever phosphatases are active. When the pathway is stimulated, inactivated GSK3 is unable to cooperate with other kinases to constitutively inhibit GS. In this study, we investigated the glycolytic potential of U87 and LN229 glioma cells during adhesion and migration through matrix-coated porous filters. The ability of glycoly- sis to support proliferation in PTEN-mutated cells was also examined in clonogenic assays. Lactic acid levels, phosphorylation changes in Akt, GSK3, and GS, and reliance of cell migration on PTEN, PI3K, and gluconeogenesis, were determined for glycolytic U87 cells that we propose benefit from their mutational loss of PTEN in avoiding lactic acidosis.

\section{Materials and methods}

\section{Materials and Cell Culture}

Chemicals and reagents, unless otherwise stated, were obtained from Sigma, St Louis, MO, USA. Human U87 MG and LN229 glioma (astrocytoma) cells (American Type Culture Collection, Rockville, MD, USA), were maintained in minimal essential media (MEM) Eagle or alpha-MEM (Cellgro, Mediatech, Herndon, VA, USA) with $10 \%$ fetal bovine serum (FBS) (Invitrogen, Carlsbad, CA, USA).

\section{Metabolic Inhibitors}

The effects of hypoxia on energy production were generated by either lowering oxygen levels or by inhibiting mitochondria respiration with sodium azide $\left(\mathrm{NaN}_{3}\right)$ (chemical hypoxia). The concentration of $\mathrm{NaN}_{3}$ was $27 \mathrm{mM}$ except when indicated in a dose curve. Selective inhibition of cytochrome oxidase with $\mathrm{NaN}_{3}$ allowed specific inhibition of aerobic energy metabolism with molecular oxygen remaining available to cellular enzymes involved in synthesis of lipid, collagen, and amino acids, fatty acid oxidation, etc. Previously, $\mathrm{NaN}_{3}(5-10 \mathrm{mM})$ was used to inhibit oxidative energy production in cultured astrocytes ${ }^{14,29,30}$ and systemically in animals. ${ }^{31-35}$ Other recent studies using cell culture and tissue-based assays have also relied on $\mathrm{NaN}_{3}$ to generate chemical hypoxia. ${ }^{36,37}$ In addition to cytochrome oxidase, $\mathrm{NaN}_{3}$ also inhibits nucleoside triphosphate diphosphohydrolase, an ecto-diphosphohydralase that hydrolyzes nucleosides extracellularly at $\mathrm{pH} 8 .^{38}$ Inflammatory cells with catalase and myeloperoxidase can oxidize $\mathrm{NaN}_{3}$ to generate nitric oxide. ${ }^{39}$ Effects of $\mathrm{NaN}_{3}$ have been shown to be independent of multiple tyrosine kinases. ${ }^{40} \mathrm{~A}$ glucose analogue, 2-deoxyglucose (2DG), inhibited glucose metabolism. Once 2DG is transported into cells and phosphorylated, it is trapped intracellularly and inhibits hexokinase ${ }^{41-43}$ Glycogenolysis of glycogen with incorporated 2DG is also inhibited. ${ }^{42,44}$ Metformin (MF), or 1,1-dimethylbiguanide, a clinical drug that inhibits gluconeogenesis, ${ }^{45,46}$ was dissolved in phosphate-buffered saline (PBS) for testing in migration assays. Wortmannin (Wm), an inhibitor of PI3K, ${ }^{47}$ was dissolved in dimethylsulfoxide as a $10 \mathrm{mM}$ stock solution for testing in adhesion and migration assays. The glycolytic migration of LN229 cells, lacking mutations of $P T E N$, was not evaluated with $\mathrm{Wm}$ and MF. 


\section{Cell Migration Assays}

Confluent cells were trypsinized on the day of assay and allowed to recover in media with $10 \%$ FBS for $2 \mathrm{~h}$ at $37^{\circ} \mathrm{C}$. Cells were centrifuged $(<500 \mathrm{rpm}$, $<5 \mathrm{~min}$ ) and resuspended at $1.5 \times 10^{6} / \mathrm{ml}$ with minimal pipetting in media for migration. For most migration assays U87 cells were suspended in 'motility media' (PBS with $0.027 \% \mathrm{CaCl}_{2} \cdot 2 \mathrm{H}_{2} \mathrm{O}$, $0.02 \% \mathrm{MgCl}_{2} \cdot 6 \mathrm{H}_{2} \mathrm{O}, 1 \% \mathrm{FBS}, 0.1 \%$ bovine serum albumin (BSA), $5 \mathrm{mM}$ sodium pyruvate, and $1 \mathrm{mg} / \mathrm{ml}$ glucose). MEM, with 1\% FBS and $0.1 \%$ BSA, was used instead of 'motility media' in assays of LN229 cells and transfected U87 cells to achieve significant levels of spontaneous migration. The 48-well modified Boyden chambers (Neuro Probe, Gaithersburg, MD, USA) were assembled with porous $(8 \mu \mathrm{m})$, polycarbonate filters (Neuro Probe), coated with $0.01 \%$ porcine gelatin. Cell suspensions were added to upper wells and chambers were incubated at $37^{\circ} \mathrm{C}$ for $4.5-5 \mathrm{~h}$ in $5 \% \mathrm{CO}_{2}$ in a routine tissue culture incubator or in an atmosphere containing $1 \% \mathrm{O}_{2}$ and $5 \% \mathrm{CO}_{2}$. Hypoxia $\left(1 \% \mathrm{O}_{2}\right)$, was maintained by a PROOX oxygen monitor (Model 110, BioSpherix, Redfield, NY, USA), within a chamber (BioSpherix) placed in a tissue culture incubator. Upon completion of the assays, filters were stained with Diff Quik (Allegiance, McGaw Park, IL, USA) and analyzed (multiple replicates per data point). Migrated cell nuclei were counted or migrated cells were digitized using a transparency scanner (Epson Perfection 2450 PHOTO, Epson America, Long Beach, CA, USA), and densitometry (UN-SCAN-It gel, Silk Scientific, Orem, UT, USA) with correction for background filter density. The two methods of quantifying cell migration (nuclear counts vs scanned cells) showed significant correlation, $r^{2}=0.9$. Assays were considered adequate for quantification when densities of migrated control cells from each well were at least several times greater than background on each filter and at least several hundred (or more) control cell nuclei migrated per chamber well. Viability of 'resting' cells (rocked at room temperature), with and without exposure to inhibitors, was tested with Trypan blue exclusion to rule out direct toxic effects on cells during the assays.

\section{Adhesion Assays}

Adhesion and deadhesion are steps in the process of migration. In separate assays, suspensions $\left(1 \times 10^{6} / \mathrm{ml}\right)$ of U87 and LN229 cells were added to $0.1 \%$ gelatin-coated multiwell plastic Costar plates (Corning, Corning, NY, USA). PBS-based motility media was used for U87 cells except for comparison assays with LN229 cells, when MEM was used for both cell types. After $2 \mathrm{~h}$ incubations at $37^{\circ} \mathrm{C}$, the plates were washed twice with PBS and stained with Diff Quik. Adherent cells were scanned and analyzed with densitometry.

\section{Invasion Assays}

U87 (100000/ml) and LN229 (200000/ml) cells, suspended in MEM with $0.1 \%$ BSA and the fluorescent dye, DiI (Molecular Probes, Invitrogen), $1 \mu \mathrm{g} / \mathrm{ml}$, were loaded in 24-well Matrigel Invasion Chambers (BD Biosciences), with and without $5 \%$ FBS and $\mathrm{NaN}_{3}$. A motogenic agent, hepatocyte growth factor (HGF), $2.5 \mathrm{ng} / \mathrm{ml}$, was also added to the bottom wells of plates loaded with LN229 cells to optimize their migration. The Matrigel-coated plates were incubated for $24 \mathrm{~h}$ at $37^{\circ} \mathrm{C}$ in routine tissue culture conditions. In each well, the fluorescence emitted from the bottom filter surface at $595 \mathrm{~nm}$ in response to excitation at $540 \mathrm{~nm}$ was quantified in a fluorescent plate reader, HTS 7000 Plus Bio Assay Reader and HTFSoft 2.0 software (Perkin Elmer, Shelton, CT, USA). Invaded cells were visualized to correlate with fluorescent results with an Axiovert S100 Fluorescent Microscope and were photographed using an AxioCam CCD camera controlled with KS300 software (Zeiss, Goettingen, Germany). Each replicate was corrected for background fluorescence of bottom wells with labeled cells loaded in the top inserts but with no HGF or serum in the bottom wells. Background fluorescence was the same as seen when no labeled cells were added.

\section{Clonogenic Assays}

Solutions of U87 cells were treated with $\mathrm{NaN}_{3}$, both $\mathrm{NaN}_{3}$ and 2DG $(2 \mathrm{mg} / \mathrm{ml})$, or no inhibitors for $5 \mathrm{~h}$ (length of migration assays) or overnight in 1\% FBSMEM with $0.1 \%$ BSA and then plated in 10\% FBSMEM. The cells, 250 per well, loaded in six-well plates were stained on the 9th day of culture and inspected to determine the number of visible clones formed.

\section{PTEN Transfection}

Replication-deficient adenoviral (Ad) expression vectors were used to restore PTEN-wild type (WT) to U87 cells. Adenoviruses with PTEN-WT and control adenovirus were constructed according to Vogelstein and colleagues. ${ }^{48,49}$ Briefly, PTEN (a kind gift from Dr Kenneth Yamada, NIH) was subcloned into the pAdTrack shuttle vector also containing a green fluorescent protein $(G F P)$ reporter transgene. pAdTrack was cotransfected with pAdEasy viral DNA into BJ5183 bacteria for homologous recombination. Recombinants were then transfected into 293 embryonic kidney cells for production of adenoviruses that were designated Ad-PTEN and Ad-control, respectively. Viral titers, as determined by plaque-formation assays, were approximately $10^{10} \mathrm{pfu} / \mathrm{ml}$. Transient transfections were accomplished by infecting the cells with Ad-PTEN or Ad-control (multiplicity of infection=10), 
$1.6-3.2 \times 10^{6} \mathrm{pfu} / \mathrm{ml}$ added. After $24-48 \mathrm{~h}$, cells were viewed with a fluorescent microscope, BH2RFCA (Olympus, Lake Success, NY, USA) to evaluate GFP as an indicator of transfection in the cells.

\section{Lactic Acid Assays}

Conditioned media was aspirated from the upper Boyden chamber wells at the end of the motility assays and from flasks of cells transfected with AdPTEN and Ad-control in separate assays. Replicates were assayed for lactic acid content using Lactate Reagent (Sigma), according to the manufacturer's instructions. Lactic acid was measured after conversion to pyruvate and hydrogen peroxide by lactate oxidase. In hydrogen peroxide, peroxidase catalyzed the oxidative condensation of chromogen precursors to produce a dye whose absorbance at $540 \mathrm{~nm}$ was directly proportional to concentrations of lactate in the samples.

\section{Alterations in Phosphorylation of Akt, GSK, and GS in Glioblastoma Cells}

Whole cell lysates containing $0.5 \%$ Igepal, a nonionic detergent, were prepared from U87 and LN229 cells. The U87 cells were incubated in motility media (with and without $\mathrm{NaN}_{3}$ ) for $4.5-5 \mathrm{~h}$ in studies to examine the results of mitochondrial inhibition that forced cell reliance on glycolysis. The transfected U87 cells (Ad-PTEN and Ad-control) were incubated in 1\% FBS-MEM for $5 \mathrm{~h}$. Lysates were electrophoresed in $10 \%$ polyacrylamide gels under reducing conditions and then transferred onto polyvinylidene difluoride membranes (Invitrogen) for immunoblotting. The amounts of total protein loaded in each lane were $10 \mu \mathrm{g}$ for all studies except $6 \mu \mathrm{g}$ was used for GSK $3 \alpha$. The membranes were blocked (Detector Block, Protein Detector Western Blot Kit LumiGLO System, Kirkegaard \& Perry Laboratories, Gaithersburg, MD, USA) and reacted with anti-Akt1 $(1 \mu \mathrm{g} / \mathrm{ml})$, antiphospho(p)-Akt (Thr 308) (1:500), anti-pGSK3 $\alpha$ (Ser 21) $(2 \mu \mathrm{g} / \mathrm{ml})$ (Upstate Inc., Lake Placid, NY, USA), anti-GS (1:1000) (Chemicon, Temecula, CA, USA), anti-Akt1, anti-pAkt1 (Ser 473), anti-GSK3 $\beta$, antipGSK3 $\beta$ (Ser 9), anti-GSK3 $\alpha$ (Ser 21), anti-GSK3 $\alpha / \beta$ (Ser 21/9), anti-pGS (Ser 640) (1:1000) (Cell Signaling), and anti-actin (1:500) (Sigma). The secondary antibodies, 1:5000 (Kirkegaard \& Perry Laboratories) were horseradish peroxidase (HRP)-labeled antisheep for some reactions with anti-Akt1 and antipGSK3 $\alpha$ (Ser 21), HRP-anti-rabbit for anti-pAkt (Thr 308), anti-pAkt (Ser 473), anti-pGSK3 $\beta$ (Ser 9), and anti-pGS (Ser 640), and anti-actin, and HRPanti-mouse for anti-GS and anti-pGSK3 $\alpha$ (Ser 21). A rabbit secondary antibody (Jackson ImmunoResearch, West Grove, PA, USA) was also used for anti-Akt, anti-pAkt (Ser 473), and anti-pGSK3 $\alpha / \beta$
(Ser 21/9). Bands were visualized with HRP conversion of a luminol-based solution to produce chemiluminescence, digitized, and analyzed. Band densities were corrected for adjacent background.

\section{RNA Message Expression of GS and Hypoxia Genes with Mitochondrial Inhibition}

Transcriptional regulation of GS was compared to known hypoxia genes during the time span used for migration assays to determine the contribution of transcriptional control to glycogenesis. U87 cells were incubated in PBS-based motility media (with and without $\mathrm{NaN}_{3}$ ) for $4.5 \mathrm{~h}$ (length of motility assays). Cellular RNA was isolated (RNeasy kit, Qiagen, Valencia, CA USA or TRIzol Reagent, Invitrogen). Biotinylated cDNA probes were prepared from the RNA for use on microarray blots (SuperArray Signal Transduction Pathway Finder GEArray Q Series kit, SuperArray Inc., Bethesda, MD, USA) according to the manufacturer's instructions. In all, 96 genes associated with signal transduction were available for comparison of cellular RNA expression, with and without $\mathrm{NaN}_{3}$ present. Three pairs of microarray blots were probed, scanned, and digitized to quantify message signals with densitometry. Message densities were corrected for adjacent background and normalized to cyclophilin A.

\section{Statistical Tests}

Means with 95\% confidence intervals (CIs) are stated. Differences between control cells and individual doses of inhibitors or PTEN-WT transfection were tested with two-tailed Student's $t$-tests after converting each data point to the percent of average control cell value for each assay to place all values on the same scale. The expression of results as a percent of the average control helped to control for assay to assay variability. Comparisons of control cells with multiple doses of inhibitors were tested with ANOVA (S-Plus, SPSS), using the numerical values of each data point (scanned pixels or migrated nuclei). Scanned results were corrected for background. ANOVA was also used to detect synergistic effects of multiple treatments or conditions. Variables typically included assay, inhibitor concentration, and the presence or absence of hypoxia.

\section{Results}

\section{U87 and LN229 Cell Migration with Metabolic Inhibition}

The glycolytic potential of U87 and LN229 cells was demonstrated in $4.5-5 \mathrm{~h}$ migration assays. Both cell types demonstrated migration under normal conditions that persisted when cells were forced to rely on 
glycolysis by adding a mitochondrial inhibitor, $\mathrm{NaN}_{3}$. A representative assay of U87 cells in PBSbased motility media demonstrated control migration (no inhibitors) with substantial metabolic reserves, as indicated by comparable levels of glycolytic migration $\left(\mathrm{NaN}_{3}\right.$ inhibition of mitochondria) and hypoglycemic migration (two-fold greater amounts of 2DG present than media glucose) (Figure 1a). However, cell migration was significantly $(P<0.00001)$ vulnerable when both metabolic inhibitors were present as shown in the averaged results of three assays (Figure 1b). Comparisons with ANOVA confirmed significant $(P<0.0001)$ synergy between $\mathrm{NaN}_{3}$ and 2DG for inhibiting U87 migration. Levels of lactate produced in three migration assays of U87 cells exposed to 2DG were significantly lower $(P$-value $<0.02)$ than the levels produced by control cells (no inhibitors). In these assays, lactate levels produced by migrated control cells and cells exposed to $\mathrm{NaN}_{3}$ were $4.03(95 \%$ $\mathrm{CI}=3.2-4.86)$ and $5.07(95 \% \mathrm{CI}=4.43-5.71) \mathrm{mmol} / \mathrm{l}$, respectively, (Figure 1c). Comparisons with ANOVA for lactate production showed a significant $(P<0.001)$ effect of 2DG, a trend for synergistic effects of $2 \mathrm{DG}$ and $\mathrm{NaN}_{3}(P=0.056)$, and no effect for $\mathrm{NaN}_{3}$ alone $(P=0.306)$.

In three representative assays, the migration of LN229 cells in the presence of $\mathrm{NaN}_{3}$ was reduced

Figure 1 Glycolytic migration of glioma cells. (a) Representative assay of U87 cell migration in Boyden chambers, without and with metabolic inhibitors. Chemical hypoxia was achieved with $27 \mathrm{mM} \mathrm{NaN}_{3}$ to force reliance on glycolysis. Glucose metabolism was inhibited by 2-deoxyglucose (2DG), $2 \mathrm{mg} / \mathrm{ml}$, competition of glucose, $1 \mathrm{mg} / \mathrm{ml}$, in motility media. Glycolytic migration (mitochondria inhibited) was sensitive to 2DG. Filters contained $8 \mu \mathrm{m}$ pores and were coated with $0.01 \%$ gelatin. Each replicate of cells that migrated in a single well is $3 \mathrm{~mm}$ in diameter. Diff Quik stain. (b) Migration of U87 cells, with and without inhibitors, quantified by counts of migrated cell nuclei (black bars) and densitometry of migrated cells (white bars). Means of three assays (2-4 replicates each) with $95 \%$ CIs are expressed as percent of control (average migration with no inhibitors). Hypoxic migration was significantly sensitive to 2DG $(P<0.00001)$. Synergy was confirmed with ANOVA. The two methods of quantifying cell migration (nuclear counts and scanned cells) showed significant correlation, $r^{2}=0.9$. (c) Extracellular lactic acid (mmol/l) released by migrating U87 cells in three migration assays as described above. Extracellular lactate levels in wells of migrated U87 cells exposed to 2DG (with or without chemical hypoxia) decreased significantly $(P<0.02)$, from average levels of the control cells (no inhibitor exposure). (d) Migration of LN229 cells, with and without inhibitors, quantified by densitometry of migrated cells. MEM was used rather than PBS-based motility media and glucose $(1 \mathrm{mg} / \mathrm{ml})$ was competed with $2 \mathrm{DG}, 1 \mathrm{mg} / \mathrm{ml}$. Means of three assays (at least three replicates each) with 95\% CIs are expressed as percent of control. Both normoxic and hypoxic migration were significantly sensitive to 2DG $(P<0.00001)$. Migration was also sensitive to $\mathrm{NaN}_{3}$ alone $(P<0.0001)$ but remained at $74.3 \%$ of control levels. Student's $t$-tests were used for comparisons of individual treatments with control. Additional results of ANOVA calculated with raw data values for U87 cells are given in the text. Cell viability (Trypan blue exclusion) of cells exposed to inhibitors at room temperature during the $5 \mathrm{~h}$ assays was unaffected. Significant $P$-values are indicated $(*)$.
$(P<0.0001)$, but only to $74.3 \% \quad(95 \% \mathrm{CI}=65.9-$ $82.7 \%$ ) of control levels. Migration in 2DG, alone and combined with $\mathrm{NaN}_{3}$, was significantly reduced $(P<0.00001)$ (Figure 1d). There was no significant

a
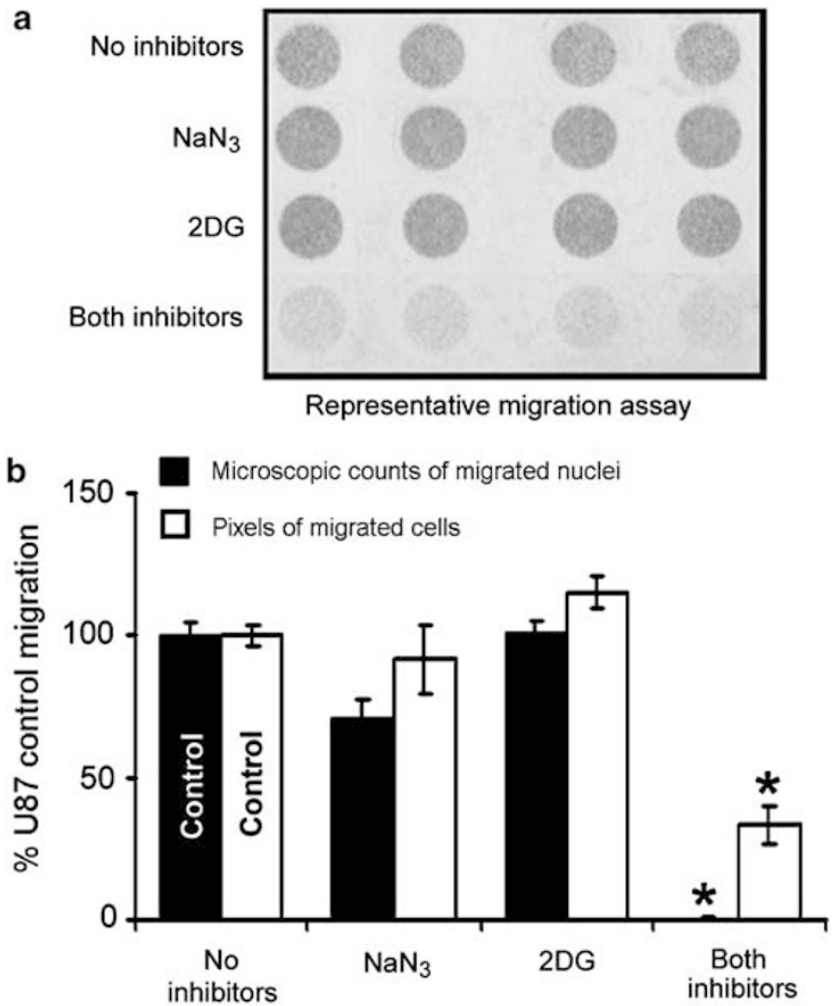

C

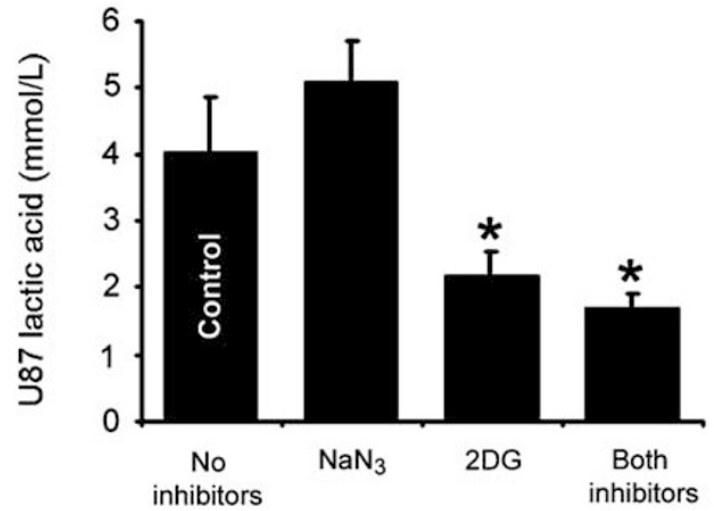

d

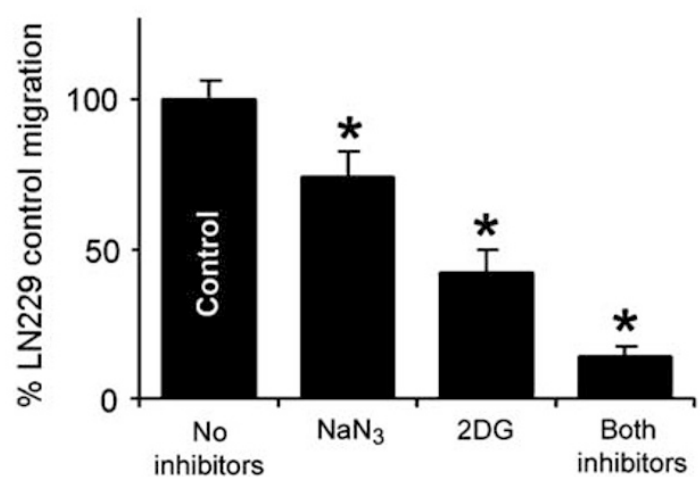


$(P=0.28)$ difference in the amounts of lactic acid released into the media by LN229 cells exposed to $\mathrm{NaN}_{3}$ compared to levels for control cells. Lactic acid released from LN229 cells exposed to 2DG, with and without $\mathrm{NaN}_{3}$, was significantly reduced $(P<0.00001)$ compared to levels released by control cells (not shown).

\section{U87 and LN229 Cell Adhesion with only Glycolytic ATP Available}

Cell adhesion and deadhesion are important steps in the migration process. In MEM, both U87 and LN229 cells maintained significant levels of glycolytic adhesion but U87 cells demonstrated increased sensitivity to 2DG compared to control adhesion (no inhibitors). U87 adhesion with separate exposures to 2DG and $\mathrm{NaN}_{3}$ were $78 \%$ (95\% CI $=73-$ $83 \%)$ and $98 \%(95 \% \mathrm{CI}=94-102 \%)$, respectively, of control levels. Levels of LN229 adhesion with separate exposures to 2DG and $\mathrm{NaN}_{3}$ were $105 \%$ $(95 \% \mathrm{CI}=102-108 \%)$ and $89 \%(95 \% \mathrm{CI}=84-94 \%)$, respectively, of control levels. Levels of U87 and LN229 adhesion with combined exposure to 2DG, $1 \mathrm{mg} / \mathrm{ml}$, and $\mathrm{NaN}_{3}$ were $1 \%(95 \% \mathrm{CI}=0-2 \%)$ and $22 \%(95 \% \mathrm{CI}=9-35 \%)$, respectively, of control adhesion for each cell line (Figure 2). Comparisons with ANOVA showed significant synergy for both inhibitors on the cells $(P<0.0001)$. Significant differences $(P<0.01)$ occurred between the two cell types for exposure to 2DG (each concentration) with $t$-tests and for all doses in chemical hypoxia using ANOVA $(P<0.02)$.

\section{Invasive Migration, with and without Mitochondrial Inhibition}

Assays of $24 \mathrm{~h}$ cellular invasion through filter pores occluded by Matrigel, a basement membrane material, provided a more rigorous (longer) evaluation of the glycolytic potential in U87 and LN229 cells. Fluorescence of invaded U87 cells that relied on glycolysis $\left(\mathrm{NaN}_{3}\right.$ present) in a chemoattractant $0-5 \%$ gradient of FBS was comparable to control invasion (no inhibitors) fluorescence. Chemokinetic invasion ( $5 \%$ FBS in top and bottom wells) by glycolytic cells was $79.1 \%(95 \% \mathrm{CI}=69.7-88.5 \%)$ of chemoattractant control (no $\mathrm{NaN}_{3}$ ) levels. Invasion against a reversed (5-0\%) gradient of FBS was limited to $15.7 \% \quad(95 \% \quad \mathrm{CI}=10.6-20.8 \%) \quad$ of chemoattractant invasion and was not evaluated for changes when mitochondria were inhibited (Figure 3a). Glycolytic invasion with 1 and $2 \mathrm{mg} / \mathrm{dl}$ 2DG was reduced to $59.3(95 \% \mathrm{CI}=52.3-66.3 \%)$ and $17.3 \%(95 \%$ $\mathrm{CI}=3.9-30.7 \%$ ), respectively, of control invasion (no inhibitors and $0-5 \%$ FBS gradient) (Figure $3 \mathrm{~b}$ ). Glycolytic invaded cells ( $\mathrm{NaN}_{3}$ present) uniformly exhibited rounded shapes. Whereas, most invasive cells without $\mathrm{NaN}_{3}$ present were also rounded, a few cells did spread out as shown (Figure 3a, lower panels). HGF-stimulated LN229 cells, with their mitochondria inhibited by $\mathrm{NaN}_{3}$, demonstrated $108.3 \%(95 \% \mathrm{CI}=94.5-122.1 \%)$ and $109.9 \%(95 \%$ $\mathrm{CI}=96.5-122.9 \%$ ) levels of control (no $\mathrm{NaN}_{3}$ and $0-5 \%$ FBS gradient) invasion for chemoattraction and chemokinesis, respectively, in two assays (not shown).

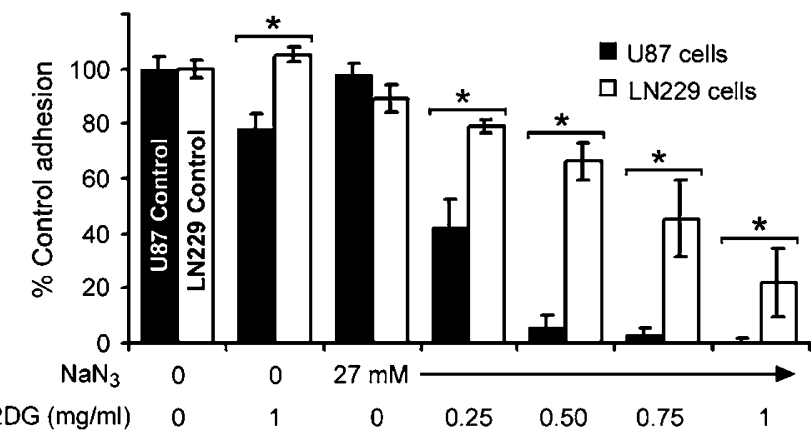

Figure 2 Glycolytic adhesion of astrocytoma cells. Adhesion and deadhesion as components of the migration process were tested in U87 and LN229 cells plated in MEM on $0.1 \%$ gelatin-coated 24well plastic plates, two to three replicates per plate, in separate assays. Substantial cell adhesion remained when mitochondria were inhibited by $\mathrm{NaN}_{3}$ but glycolytic adhesion was sensitive to 2DG. Comparisons with ANOVA showed significant $(P<0.001)$ synergy for both $\mathrm{NaN}_{3}$ and 2DG on the cells. However, the two types of cells showed significant differences $(P<0.01$, as indicated $(*)$ ) at each dose of 2DG. Comparison with ANOVA also showed a significant difference, $P<0.02$, between the two cell lines with U87 cells displaying greater sensitivity of glycolytic adhesion to 2DG.

\footnotetext{
Figure 3 Glycolytic invasion of Matrigel by glioma cells. (a) U87 cells invaded filter membranes (8 $\mu$ m pores occluded with Matrigel basement membrane matrix) in $24 \mathrm{~h}$ assays. Invasion without any inhibitors was comparable for responses to either a chemoattractant gradient (0-5\% FBS) or chemokinesis ( $5 \%$ FBS in top and bottom wells). Invasion in response to the $0-5 \%$ FBS gradient, without and with mitochondrial inhibition by $\mathrm{NaN}_{3}$, was comparable. With $\mathrm{NaN}_{3}$ present, chemokinetic invasion was slightly reduced to $79.1 \%$ (95\% $\mathrm{CI}=69.7-88.5 \%$ ) of control invasion (gradient response with no $\left.\mathrm{NaN}_{3}\right)(P<0.01$, as indicated $(*)$ ). In the bottom panels, the morphology of invaded U87 cells on the bottom surface of Matrigel-coated filters, with and without mitochondrial inhibition, is shown, as indicated by the arrows. Whereas, most of the invasive cells without $\mathrm{NaN}_{3}$ present were rounded, a few displayed cell spreading as shown. Glycolytic cells that invaded in response to 5\% FBS (with or without a chemoattractant gradient), uniformly exhibited rounded shapes without cell spreading. Each dark pore is $8 \mu \mathrm{m}$ in diameter. DiI fluorescence was measured at $595 \mathrm{~nm}$. In two separate assays of LN229 glioma cells responding to $5 \% \mathrm{FBS}$ and hepatocyte growth factor, $2.5 \mathrm{ng} / \mathrm{ml}$, no differences were demonstrated in chemoattractant and chemokinetic invasion with $\mathrm{NaN}_{3}$ present compared to its absence (not shown). (b) The addition of 2DG to invading U87 cells, with and without $\mathrm{NaN}_{3}$ present, demonstrated the dependence of invasive migration in hypoxic conditions on glycolysis. With either 1 or $2 \mathrm{mg} / \mathrm{ml}$ of 2DG present, hypoxic invasion was significantly reduced $(P<0.01$, as indicated $(*))$.
} 
a

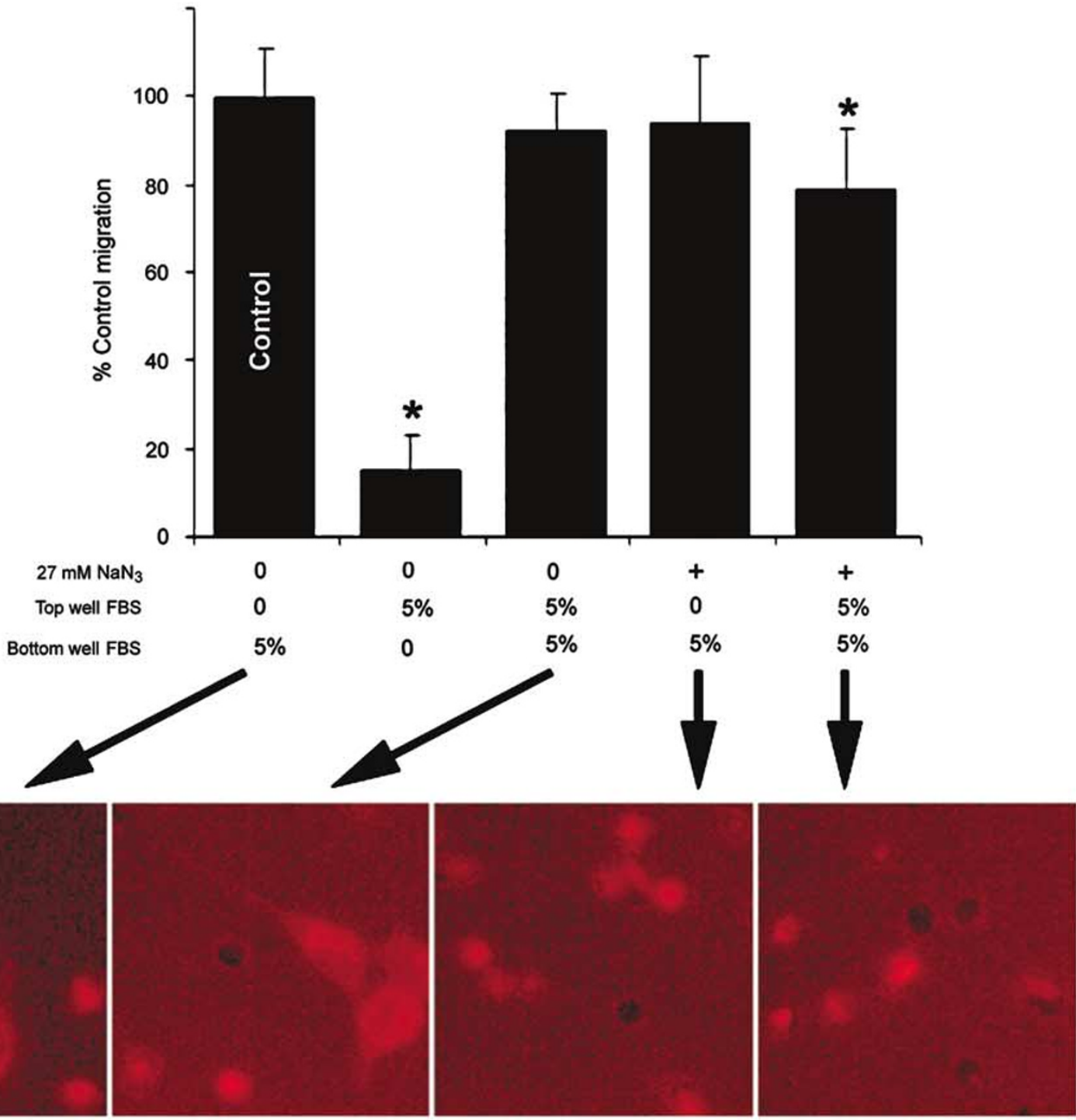

b

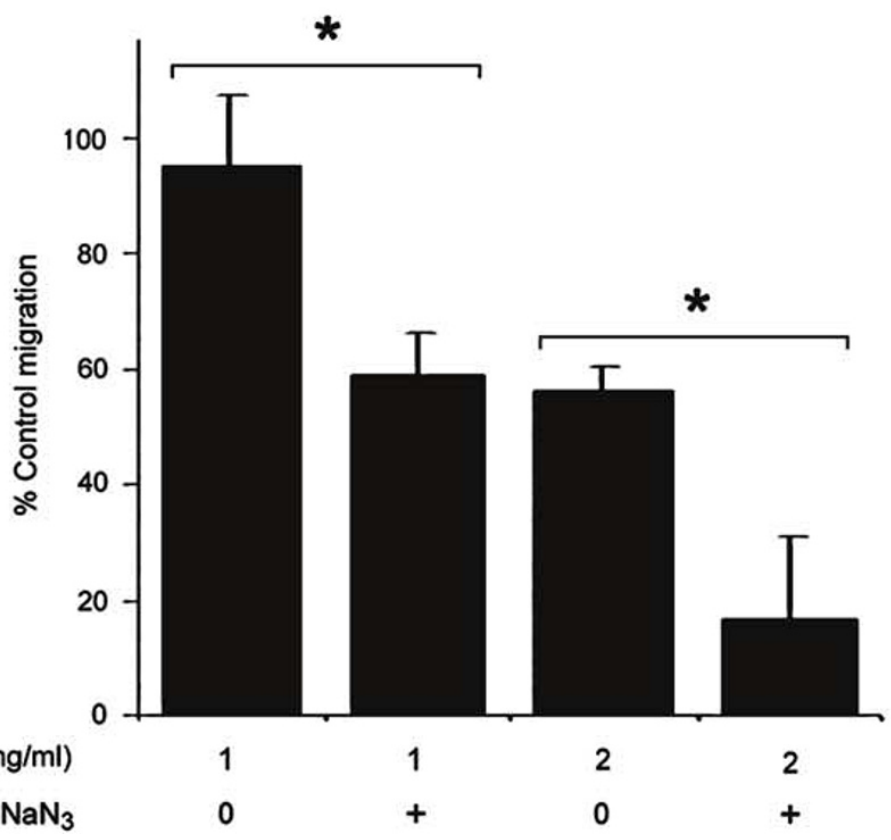


Migration and Release of Lactic Acid by U87 Cells in $1 \% \mathrm{O}_{2}$

Cell migration occurred in true hypoxia $\left(\begin{array}{lll}1 \% & \mathrm{O}_{2}\end{array}\right)$, with and without mitochondrial inhibition. U87 cells retained migration in PBS-based migration media in $1 \% \mathrm{O}_{2}$, without or with $10-50 \mathrm{mM} \mathrm{NaN}_{3}$ present. For each dose of $\mathrm{NaN}_{3}$, with normal or $1 \% \mathrm{O}_{2}$, cell migration either remained similar to control migration (normoxia without $\left.\mathrm{NaN}_{3}\right)$ or increased $(P<0.04)$ up to $129.4 \%$ (95\% CI $=108.4-150.4 \%$ ) (Figure 4a). Levels of extracellular lactic acid released by cells exposed to $10-50 \mathrm{mM} \mathrm{NaN}_{3}$ in normal or $1 \% \mathrm{O}_{2}$ were elevated in a small plateau $(P<0.05)$ with the highest value at $119.7 \%(95 \% \mathrm{CI}=113.0-126.4 \%)$ of the average control value (Figure $4 \mathrm{~b}$ ).

\section{Clonogenic Potential of Glycolytic U87 Cells}

Retention of potential for proliferation following hypoxic migration of invasive tumor cells would correlate with the malignant behavior of glioblastomas seen clinically. In three assays, cells treated with $\mathrm{NaN}_{3}$ for $5 \mathrm{~h}$ prior to plating produced $82 \%(95 \% \mathrm{CI}=58-$ $106 \%$ ) of the number of clones produced by untreated cells after 9 days. Overnight $(18 \mathrm{~h})$ exposure to $\mathrm{NaN}_{3}$ and 2DG was required to abolish the clonogenic potential in all three assays with results at $0.3 \%$ $(95 \% \mathrm{CI}=0-0.8 \%)$ of control levels (not shown).

\section{Phosphorylation of Akt, GSK3, and GS}

Lysates of glioblastoma cells (U87 or LN229) plated for $5 \mathrm{~h}$ were analyzed on immunoblots reacted with anti-Akt1, anti-pAkt 1 (Thr 308), anti-pAkt 1 (Ser 473), anti-pGSK3 $\alpha$ (Ser 21), anti-GSK3 $\beta$, anti-pGSK3 $\beta$ (Ser 9), anti-pGSK3 $\alpha / \beta$ (Ser 21/Ser 9), anti-actin, antiGS, and anti-pGS (Ser 640). Cell lysate loading was equalized for total protein with $10 \mu \mathrm{g}$ per lane. The effects of chemical hypoxia on the deregulated PI3K/ Akt pathway were studied in U87 cells with mutated PTEN. When paired sets of U87 cells were cultured, with and without $\mathrm{NaN}_{3}$, the phosphorylation of Akt 1 (Thr 308) and GSK3 $\alpha$ (Ser 21) increased $3.3 \times$ and $2.9 \times$, respectively, in the presence of the mitochondrial inhibitor that forced the cells to be glycolytic. A slight increase $(1.3 \times)$ in total Akt1 was present in the $\mathrm{NaN}_{3}$-exposed cells. Concentrations of actin remained the same. Phosphorylation of GS in glycolytic cells was reduced down to $12.3 \%$ of the control level (cells without $\mathrm{NaN}_{3}$ ), indicating increased enzyme activity when the mitochondria were inhibited (Figure 5). A moderate reduction in GS phosphorylation, $65.7 \%$ of the normal level, was seen in $1 \% \mathrm{O}_{2}$ (not shown). In the mutated PTEN cell line, U87, the level of GS was 4.63X greater compared to LN229 cells with intact $P T E N$. The increase $(2.29 \times)$ in the phosphorylated (inactive) form of GS was only half as much increased in U87 cells. Therefore, a larger fraction and absolute amount of GS was active in U87 cells under normal
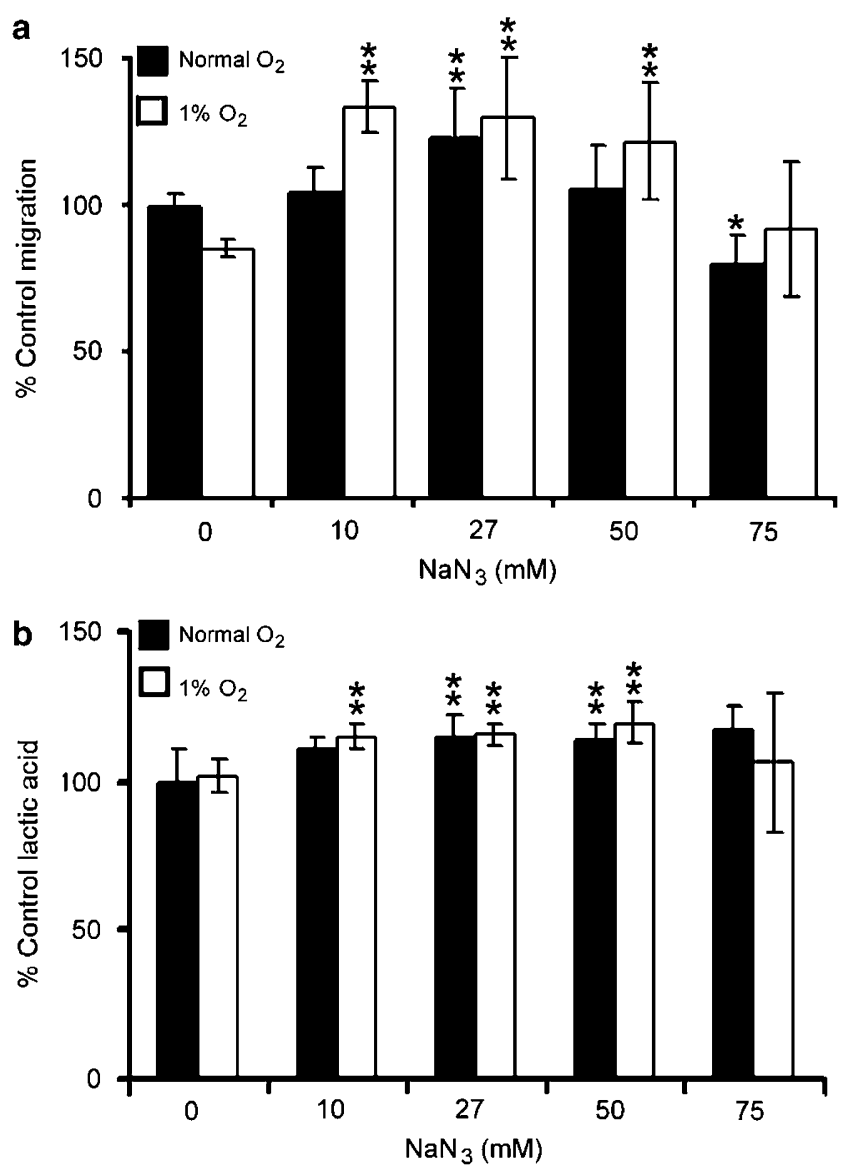

Figure 4 Migration of U87 cells in true hypoxia, with and without additional inhibition of mitochondria. (a) Resistance of U87 cells to mitochondrial inhibition by $\mathrm{NaN}_{3}$, under either normoxia (black bars) or $1 \% \mathrm{O}_{2}$ (white bars). Cell migration either increased or remained at control levels when $\mathrm{NaN}_{3}(10-50 \mathrm{mM})$ was added. Significantly increased migration $\left(P<0.04,10-50 \mathrm{mM} \mathrm{NaN}_{3}\right)$ and decreased migration $\left(P=0.0003,75 \mathrm{mM} \mathrm{NaN}_{3}\right)$ are indicated $(* *)$ and $(*)$, respectively. Osmotic stress at the highest concentration of $\mathrm{NaN}_{3}$ may explain the reversal of its effect. Averages of combined replicates (greater than 15 for each data point) are shown with $95 \%$ CIs. (b) Release of extracellular lactic acid by migrating U87 cells under normoxic conditions (black bars) or 1\% $\mathrm{O}_{2}$ (white bars) with increasing levels of $\mathrm{NaN}_{3}$ added. Hypoxia $\left(1 \% \mathrm{O}_{2}\right)$ and $10 \mathrm{mM} \mathrm{NaN}_{3}$ failed to produce significant elevations of extracellular lactate $(P>0.05)$ but a plateau of slightly increased $(P<0.05$, as indicated $(* *))$ levels did occur at higher $\mathrm{NaN}_{3}$ concentrations. Each lactate level was expressed as a mean percent of average control (normoxic) level of extracellular lactate with $95 \%$ CIs. Combined aliquots of three to four replicates for each data point, repeated in four to six Boyden assays, are represented. Cell viability was unaffected during the assays.

conditions. Correspondingly, the levels of GSK3 $\beta$ and pGSK $3 \beta$ were $5.88 \mathrm{X}$ and $11.6 \times$ greater, respectively, in U87 cells than in LN229 cells (not shown).

\section{Lack of Transcriptional Regulation on GS in U87 Cells Responding to Mitochondrial Inhibition}

The potential contribution of transcriptional regulation of GS activity induced by mitochondrial inhibition for $4.5 \mathrm{~h}$ was evaluated among 96 signal 


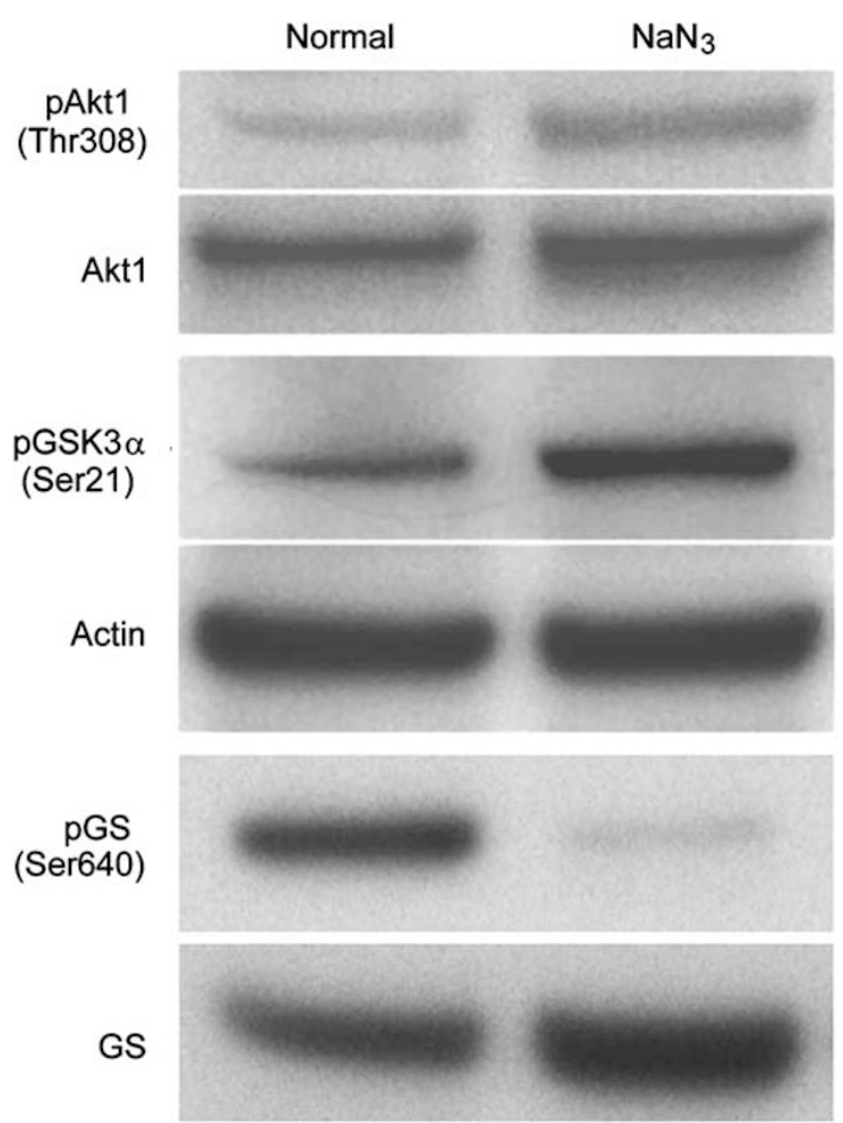

Figure 5 Forcing U87 cells to rely on glycolysis increased signaling in the branch of the PI3K/Akt pathway that regulates glycogen synthase (GS). With exposure to $\mathrm{NaN}_{3}$ for $5 \mathrm{~h}$ in freshly plated cells, Akt1 and glycogen synthase kinase $3 \alpha$ (GSK3 $\alpha$ ) phosphorylation increased on residues, threonine 308 and serine 21, respectively, reflecting loss of GSK3's constitutive inhibitory control on GS activity. When mitochondrial were inhibited, densities of the digitized bands increased $3.3 \times$ and $2.9 \times$ for phosphorylated forms of Akt1 (Thr 308) and GSK3 $\alpha$ (Ser 21), respectively. Additional assays showed that inhibition of mitochondria to force increased glycolysis led to decreased phosphorylation of glycogen synthase (GS) at serine 640 to $12.3 \%$ of levels in normal conditions. In $1 \% \mathrm{O}_{2}$, GS phosphorylation decreased to $65.7 \%$ of levels in normal conditions (not shown). U87 cell lysates $(10 \mu \mathrm{g}$ total protein per lane) were immunoblotted with anti-pAkt1 (Thr 308), anti-Akt1, anti-GS and anti-pGS (Ser 640). Lysates ( $6 \mu \mathrm{g}$ total protein per lane) were immunoblotted with anti-pGSK3 $\alpha$ (Ser 21), and a control antibody, anti-actin.

transduction-related genes. Messages for known hypoxia-associated proteins, early growth response-1 (egr-1) and fos, ${ }^{50-54}$ were included. Whereas, message levels for glycogen synthase did not demonstrate significant changes, messages for fos and egr-1, 0 and $16.8 \%$, respectively, of a control message (cyclophilin A), increased to 46.3 and $42.4 \%$, respectively, in U87 cells (Figure 6).

\section{Inhibition of PI3K by Wortmannin (Wm), with and without Mitochondrial Inhibition}

Wm, a noncompetitive inhibitor of PI3K, was used to examine the effect of PI3K/Akt pathway inhibi-

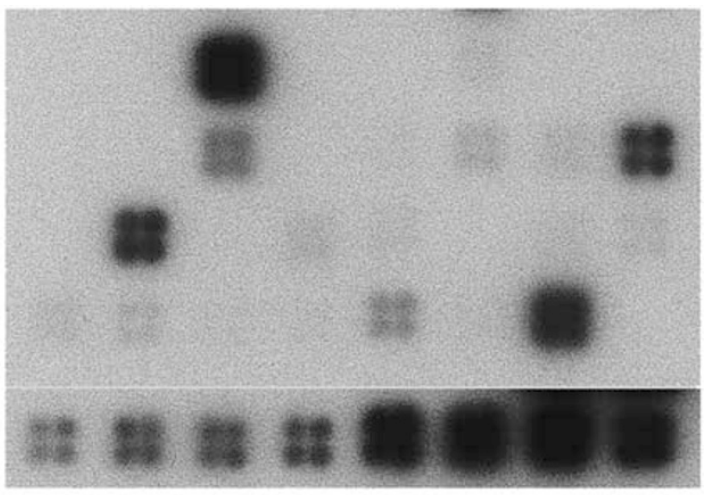

b

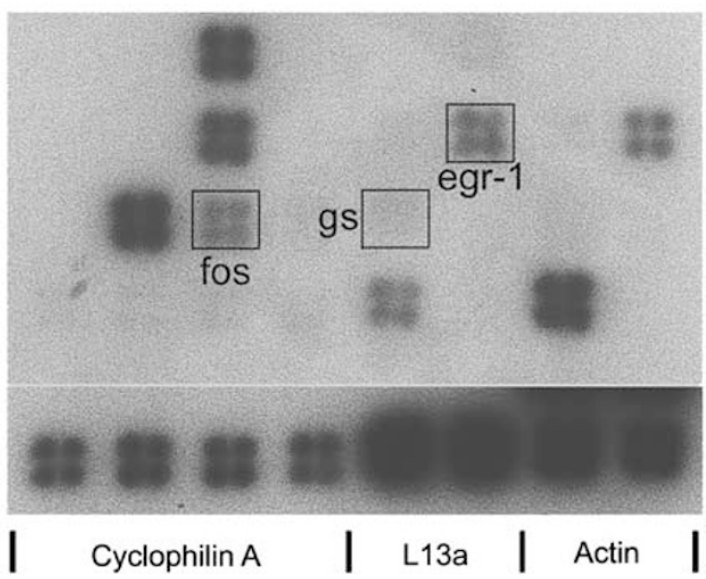

Figure 6 Lack of altered glycogen synthase (gs) gene expression in the transcriptional response to hypoxia. Adding $\mathrm{NaN}_{3}$ to force U87 cells to rely on glycolysis for $5 \mathrm{~h}$ did not increase RNA expression of glycogen synthase although it did increase messages of hypoxia-associated genes. RNA was harvested from U87 cells plated in PBS-based motility media, with and without exposure to $\mathrm{NaN}_{3}$. Biotin-labeled cDNA generated from the RNA was used to probe microarray blots for various signal transduction pathway components and controls (selected by the manufacturer). (a) and (b) represent a pair of microarray blots probed with cDNA prepared from cells incubated without and with $\mathrm{NaN}_{3}$, respectively. When cells were reliant on glycolysis (b), the expression of glycogen synthase did not appreciably increase, but expression of fos and egr-1, 46.3 and $42.4 \%$, respectively, of control cyclophilin $A$ levels, were significantly elevated compared to levels without mitochondrial inhibition shown in (a). Controls for each blot, shown as the bottom rows in (a) and (b), included homo sapiens cyclophilin A, ribosomal protein L13a, and beta actin.

tion on U87 cell migration and adhesion in PBSbased motility media. Wm inhibited spontaneous motility and adhesion under normal conditions and when cells were forced to be glycolytic by inhibiting mitochondria with $\mathrm{NaN}_{3}$. At each concentration of $\mathrm{Wm}, 10 \mathrm{nM}$ and greater, significant inhibition occurred for both cell functions, with or without mitochondrial inhibition. In comparison to controls (average cell function with no inhibitors), $30 \mathrm{nM}$ Wm inhibited glycolytic cell migration down to $8.5 \% \quad(95 \% \quad \mathrm{CI}=4.5-12.5 \%)$ (Figure $7 \mathrm{a}$ ) and cell adhesion down to $33.4 \%$ (95\% $\mathrm{CI}=26.9-39.9 \%)$ (Figure 7b). Cell migration differed significantly from control migration for all Wm concentrations without $\mathrm{NaN}_{3}$ exposure $(P<0.02)$, and at 10 and 


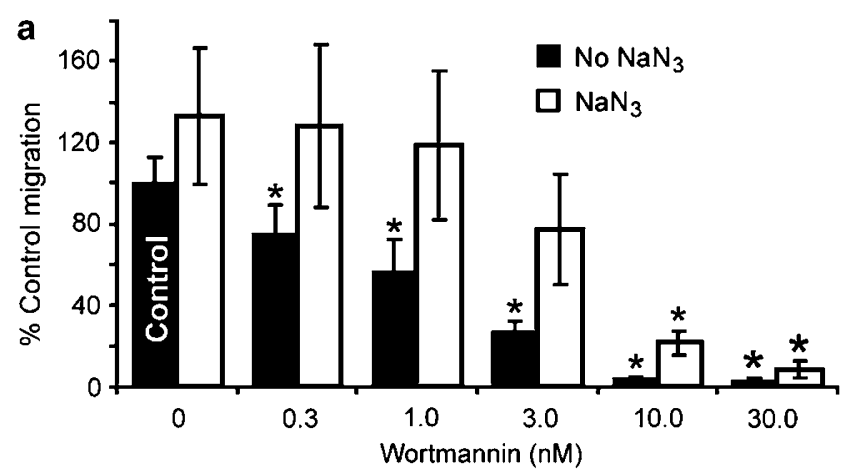

b

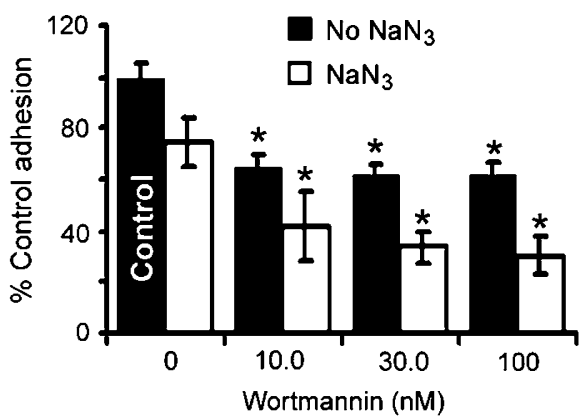

Figure 7 An inhibitor of PI3K, wortmannin (Wm), mediated suppression of cell adhesion and migration, without (black bars) and with (white bars) inhibition of mitochondria by $\mathrm{NaN}_{3}$. (a) Wm, $10.0-30.0 \mathrm{nM}$, significantly decreased $(P<0.001$, as indicated $(*)$ ), normal or glycolytic $\left(\mathrm{NaN}_{3}\right.$ present) cell migration. Replicates (at least four per data point) were combined from multiple assays. (b) Wm, $10 \mathrm{nM}$ and greater, inhibited normal and glycolytic cell adhesion. Each Wm dose showed significant $(P<0.01$, as indicated $(*))$, inhibition of cell adhesion compared to control cells using Student's $t$-tests. A greater effect of Wm inhibition on glycolytic migration than on adhesion is consisten with enhancement of cell migration by limited deadhesion. Mean percent of average control (no inhibitors present) for cell adhesion and migration with $95 \%$ CIs are shown. No significant interactions between $\mathrm{NaN}_{3}$ and $\mathrm{Wm}$ concentration were detected for either cell function with ANOVA using raw data. Other ANOVA results are given in the text.

$30 \mathrm{nM}$ concentrations $(P<0.0001)$ when $\mathrm{NaN}_{3}$ was present (Figure 7a). Comparison with ANOVA found that Wm's concentration had a significant effect $(P<0.001)$ on both adhesion and motility. Also, each dose of Wm significantly inhibited $(P<0.01$, student's $t$-tests) adhesion compared to levels for control cells, with or without $\mathrm{NaN}_{3}$ also present. No significant interactions between $\mathrm{NaN}_{3}$ and $\mathrm{Wm}$ concentration were detected for either cell function with ANOVA. Greater effects of Wm on migration compared to adhesion in glycolytic cells may be explained by the favorable contribution of deadhesion, as well as adhesion, to cell migration.

\section{Effect of Restoring PTEN's Regulation of the PI3K/Akt Pathway on Glycolytic Cell Migration}

Following Ad-PTEN transfections, at least $80 \%$ of the U87 cells exhibited GFP. Although adenoviral transfections nonspecifically inhibited cell migra- tion, most transfections permitted sufficient Adcontrol-infected cell migration to meet the criteria for evaluation and were analyzed for the effects of restoring PTEN on glycolytic migration. Each time PTEN was restored in U87 cells, their exposure to $\mathrm{NaN}_{3}$ led to significantly decreased $(P<0.002)$ migration down to $45.7 \%(95 \% \mathrm{CI}=41.2-50.2 \%)$ of cell migration levels without mitochondrial inhibition, as shown in four assays (Figure 8). ANOVA also demonstrated significantly decreased $(P<0.0001)$ glycolytic migration $\left(\mathrm{NaN}_{3}\right)$ in cells with restored PTEN while controlling for baseline variation among the assays. Immunoblots of U87 cells infected with Ad-PTEN or Ad-control showed that when PTEN was restored, phosphorylations of Akt and GSK3 isoforms were strongly inhibited (Figure 8b). Although the stimulatory effect of $\mathrm{NaN}_{3}$ on the pathway persisted in PTEN-restored cells, it was less powerful. The stimulatory effect of $\mathrm{NaN}_{3}$ on phosphorylation of GSK3 $\alpha$ and $\beta$ isoforms in Adcontrol-infected cells was $1.82 \times$ and $1.98 \times$ greater, respectively, than in cells infected with Ad-PTEN (not shown).

In two assays when freshly plated U87 cells retained their spindled morphology for $5 \mathrm{~h}$ in $\mathrm{NaN}_{3}$, conditioned media of Ad-PTEN-infected cells contained significantly $(P=0.02)$ greater levels of lactic acid compared to Ad-control cells, $118.2 \%$ $(95 \% \mathrm{CI}=110.2-126.2 \%)$. In a third assay with numerous rounded cells present after $5 \mathrm{~h}$, the difference in lactic acid levels was no longer present, presumably due to the activity of lactate dehydrogenase released from cells undergoing cell death more easily in the presence of PTEN.

\section{Inhibition by Metformin (MF) of Glycolytic Cell Migration}

An inhibitor of gluconeogenesis, MF, also suppressed U87 cell migration when cells were forced to be glycolytic by adding $\mathrm{NaN}_{3}$. Significant inhibitions $(P<0.02)$ were obtained for U87 cells exposed to $\mathrm{MF}, 1$ and $3 \mathrm{mM}$, during migration assays, with and without $1 \mathrm{mM}$ MF in tissue culture during a previous overnight incubation. Cells exposed to MF, $1 \mathrm{mM}$, overnight and during the assays, migrated at $66.2 \%(95 \% \mathrm{CI}=57.8-74.6 \%)$ of the average glycolytic cell migration (Figure 9). Comparisons with ANOVA showed that MF treatments during the assay and overnight prior to the assay were significant, $P<0.001$ and 0.0001 , respectively, with synergy for both MF exposures, $P=0.02$.

\section{Discussion}

This study demonstrated the capacity of malignant astrocytes to maintain survival and energy for adhesion, migration through porous filters, and invasion of Matrigel, under conditions when only glycolytic ATP was available. Suppression of 


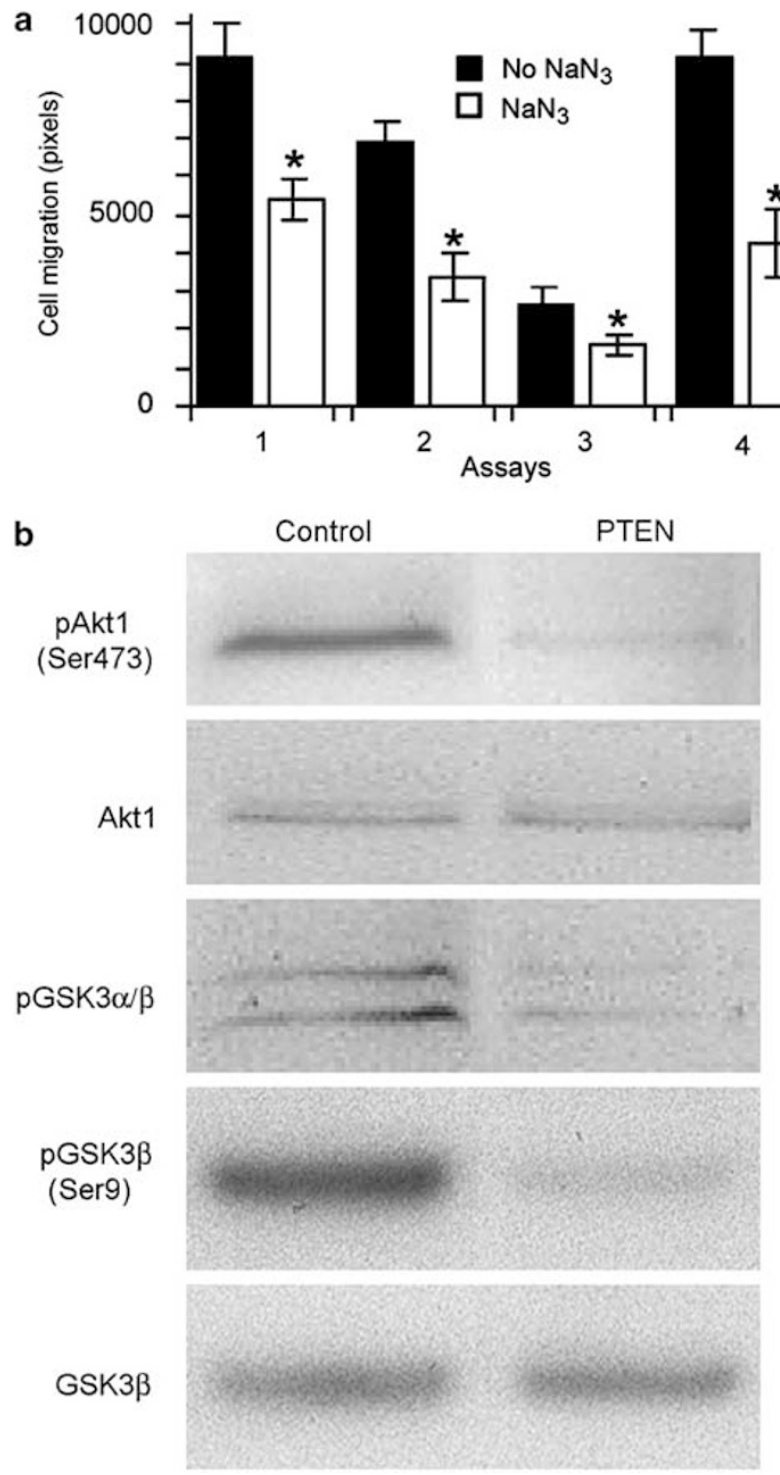

Figure 8 Suppression of U87 migration in chemical hypoxia attributed to restoration of PTEN's inhibition of phosphorylation events in the PI3K/Akt pathway. (a) Restoration of PTEN suppressed glycolytic cell migration in U87 cells. Migration of Ad-PTEN-infected U87 cells was significantly decreased $(P<0.002$, as indicated $(*))$ when they were glycolytic $\left(\mathrm{NaN}_{3}\right.$ present) to $45.7 \%(95 \% \mathrm{CI}=41.2-50.2 \%)$ of cell migration (AdPTEN infected) without $\mathrm{NaN}_{3}$ present. In these four migration assays (at least six replicates per data point) glycolytic migration of Ad-control-infected cell levels remained comparable to their migration without mitochondrial inhibition. There were at least several hundred migrated control cells per chamber well. ANOVA using raw data also demonstrated significantly $(P<0.0001)$ decreased migration in $\mathrm{NaN}_{3}$ while controlling for baseline variation among the assays. (b) Suppression of phosphorylation events in the PI3K/Akt pathway in U87 cells with restored PTEN was confirmed on immunoblots. Levels of pAkt (Ser 473) and pGSK3 $\beta$ (Ser 9) were $8.6 \times$ and $5.1 \times$ greater in cell infected with Ad-control compared to Ad-PTEN with almost no changes in amounts of Akt and GSK3 $\beta$. Phosphorylation of GSK3 by Akt leads to its inactivation. Subsequently, GS can be dephosphorylated to mediate glycogenesis as a mechanism to remove lactic acid.

mitochondrial respiration for $5 \mathrm{~h}$ also did not interfere with the clonogenic potential of PTENmutated cells. Reliance on glycolysis is forced to

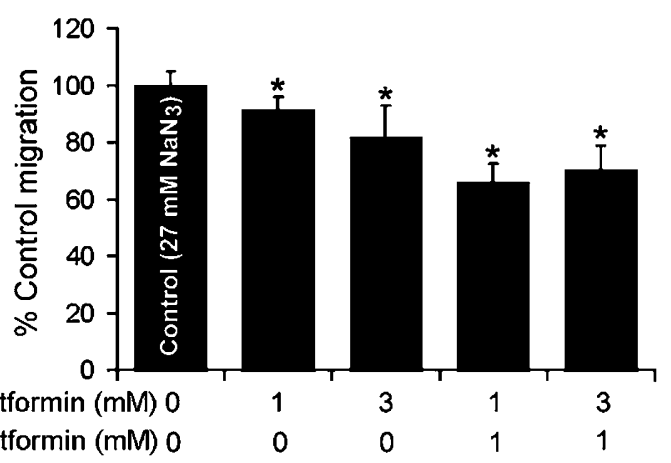

Figure 9 Metformin (MF) inhibited U87 glycolytic migration. In studies with $\mathrm{NaN}_{3}$ present in all assays, exposure to MF overnight and during the assay, suppressed migration to $66.2 \% \quad(95 \%$ $\mathrm{CI}=57.8-74.6 \%$ ) of migration with no MF present. Inhibited gluconeogenesis is proposed to interfere with conversion of lactate to glucosyl residues. Means of replicates (at least eight per data point) combined from multiple assays with $95 \%$ CIs are shown. Significant differences $(P<0.02$, as indicated $(*))$, were obtained for all MF doses using Student's $t$-tests. Comparisons with ANOVA showed that MF exposures during the assay and overnight prior to the assay were significant, $P<0.001$ and 0.0001 , respectively, with synergy for both $\mathrm{MF}$ exposures, $P=0.02$.

occur in vivo whenever mitochondrial respiration is blocked by hypoxia, mutational loss of mitochondrial proteins, or a mitochondrial inhibitor. Regions of hypoxia are commonly found in malignant gliomas and viability of primary astrocytoma cells cultured in $0.6 \%$ oxygen has verified their resistance to hypoxia. ${ }^{55}$ In this study, the in vitro motility of U87 cells persisted in $1 \% \mathrm{O}_{2}$ and when mitochondrial production of ATP was maximally inhibited by $\mathrm{NaN}_{3}$. Upregulated glycolytic production of ATP energized tumor cells as they migrated in the small wells of Boyden chambers, without external removal of lactic acid, for several hours. Although mitochondrial inhibition was progressively increased to force maximal reliance on glycolysis, the rise in extracellular lactate produced by U87 cells was only a small plateau, despite the high density (1000 cells/ $\mu \mathrm{l})$ and limited buffering capacity of PBS. By default, the control of lactate in these assays was accomplished by cell metabolism.

Storage of lactate's carbon skeletons via temporary incorporation into glycogen is a rapid adaptation in gluconeogenic cells mediated by activation (dephosphorylation) of GS. A complex hierarchy of kinases and phosphatases control GS, with GSK3 providing the major share of constitutive inhibitory control. GSK3's deactivating phosphorylation of GS declines when the PI3K/Akt pathway is stimulated by growth factors, insulin, mitochondrial inhibition, or true hypoxia, especially when PTEN is lost due to mutation. Decreased expression of PTEN was found in 29 of $42(69 \%)$ of glioblastomas from human patients based on the immunostaining of the majority of the tumor cells compared with endothelial cells and neurons as internal controls. ${ }^{28}$ On 
immunoblots, levels of PTEN were decreased in all six glioblastomas tested and levels of downstream phosphorylated (activated) Akt were increased in four of the six glioblastomas compared to samples of normal brain. ${ }^{56}$ Recently, using immunohistochemistry on patient tumor specimens, phosphorylated Akt has been found in 18 of 29 (62\%) glioblastomas and 22 of $40(55 \%)$ gliomas of any grade. Interestingly, none of the 22 gliomas with high levels of phosphorylated Akt, indicating an activated PI3K/ Akt pathway, responded to treatment with an inhibitor of epidermal growth factor signaling. However, eight of the 18 tumors with a less active PI3K/Akt pathway, shown by low levels of phosphorylated Akt, did respond to the treatment. The level of pathway activation in the specimens was also associated with tumor progression. ${ }^{57}$

Other studies have also found that PI3K/Akt pathway signaling to inactivate GSK3 is increased in hypoxic conditions. ${ }^{58-61}$ Signaling in other pathways also leads to inactivation of GSK3. ${ }^{62-64}$ The increased potential for GS activation and glycogenesis allowed by inactivated GSK3 is advantageous for tumors since the capacity for glycolytic energy production is increased whenever cells encounter hypoxia or ischemia. The buildup of lactic acid that normally shuts down glycolysis is avoided and the energy potential of carbon bonds in lactate can be preserved within glucosyl residues of glycogen, possibly in separate cellular compartments or regions. Glycogenesis can not only reserve glucose supplies for hypoxic exposures, it may also aid invasion by preventing lactic acidosis in hypoxic pseudopodia or whole cells disconnected from the vasculature and retaining lactate's carbon skeleton within glucosyl residues. Glycosyl residues can readily be utilized during aerobic energy production in another region of the cell, or on site when vascular contact is restored. By not releasing lactate extracellularly, the energy debt generated by gluconeogenesis to prevent lethal levels of lactic acidosis can be repaid during mitochondrial respiration, either elsewhere in a cell or on site at a later time.

Although the message level for GS was not altered during inhibition of mitochondria, enhanced promotion of GS activity stimulated by growth factors in PTEN-mutated cells may be coordinated with other adaptations to hypoxia and ischemia that are mediated by transcription factors responding to growth factors. Not only were message levels of fos and egr-1 elevated in hypoxia (including U87 cells in this study), they were also elevated in astrocytic cells stimulated by trophic factors. ${ }^{65-69}$ When egr-1 was expressed in glioblastoma cells by others, tumor cell adhesion and migration were greatly increased..$^{70}$ Autocrine growth factors in gliomas may strengthen adaptation to hypoxia through fos and egr-1 as well as through GS activation that is permitted by the stimulated PI3K/Akt pathway.

Although the potential for glioma cells to avoid lactic acidosis when disconnected from the vascu- lature suggests a mechanism for these cells to avoid exposure to drugs delivered by the bloodstream, the U87 cells displayed susceptibility to drugs that could prevent the initiation of glycolytic-dependent migration. In earlier studies, glycolytic migration of melanoma cells was susceptible to oxamate, an inhibitor of lactate dehydrogenase, ${ }^{2}$ but systemic inhibitory levels of oxamate are difficult to achieve. ${ }^{71-73}$ In this study, U87 glioma cell migration during mitochondrial inhibition was suppressed by 2DG, MF, and Wm. Restoration of PTEN to inhibit the PI3K/Akt pathway also suppressed glycolytic cell migration.

In summary, at least two glioma cell lines exhibited the capacity to migrate under hypoxic conditions. For the U87 glioma cell line with mutational loss of PTEN, the complex metabolic response that prevents lactic acidosis within astrocytic cells was intact and stronger under hypoxic conditions than it was when PTEN was restored. The in vitro invasive activities allowed by enhanced glycolytic energy production in PTEN-mutated glioma cells observed in this study may help to explain the aggressive behavior of PTEN-mutated glioblastomas in vivo.

\section{Acknowledgements}

We thank Jeffrey L Brodsky, PhD, Department of Biological Sciences, University of Pittsburgh, Pittsburgh, PA, USA for helpful comments and suggestions. We thank Kenneth M Yamada, MD, PhD, NIDCR, NIH, Bethesda, MD, USA for providing the PTEN construct. We acknowledge Karen B Lassige, Susan L Gleixner, and Beth Arnold, Department of Neurosurgery, University of Pittsburgh, for their technical assistance and Douglas E Moul, MD, MPH, Department of Psychiatry, University of Pittsburgh School of Medicine, for performance of ANOVA. We gratefully acknowledge funding from The Nick Eric Wichman Foundation (Ellicott City, MD), The Walter L Copeland Fund for Cranial Research of the Pittsburgh Foundation, and the American Heart Association, Ohio Valley Affiliate (AHA 9960398V).

\section{References}

1 Bolteus AJ, Berens ME, Pilkington GJ. Migration and invasion in brain neoplasms. Curr Neurol Neurosci Rep 2001;1:225-232.

2 Beckner ME, Stracke ML, Liotta LA, et al. Glycolysis as primary energy source in tumor cell chemotaxis. J Natl Cancer Inst 1990;82:1836-1840.

3 Lichtor T, Dohrmann GJ. Respiratory patterns in human brain tumors. Neurosurgery 1986;19:896-899.

4 Liang BC, Hays L. Mitochondrial DNA copy number changes in human gliomas. Cancer Lett 1996;105: 167-173. 
5 Meixensberger J, Herting $\mathrm{B}$, Roggendorf $\mathrm{W}$, et al. Metabolic patterns in malignant gliomas. J Neurooncol 1995;24:153-161.

6 Kirsch WM, Leitner JW. A comparison of the anaerobic glycolysis of human brain and glioblastoma. J Neurosurg 1967;27:45-51.

7 Terpstra M, Gruetter R, High WB, et al. Lactate turnover in rat glioma measured by in vivo nuclear magnetic resonance spectroscopy. Cancer Res 1998;58: 5083-5088.

8 Brooks DJ, Beaney RP, Lammertsma AA, et al. Glucose transport across the blood-brain barrier in normal human subjects and patients with cerebral tumours studied using [11C]3-O-methyl-D-glucose and positron emission tomography. J Cereb Blood Flow Metab 1986;6:230-239.

9 Boado RJ, Black KL, Pardridge WM. Gene expression of GLUT3 and GLUT1 glucose transporters in human brain tumors. Brain Res Mol Brain Res 1994;27: 51-57.

10 Nagamatsu S, Sawa H, Wakizaka A, et al. Expression of facilitative glucose transporter isoforms in human brain tumors. J Neurochem 1993;61:2048-2053.

11 Nishioka T, Oda Y, Seino Y, et al. Distribution of the glucose transporters in human brain tumors. Cancer Res 1992;52:3972-3979.

12 Semenza GL, Roth PH, Fang HM, et al. Transcriptional regulation of genes encoding glycolytic enzymes by hypoxia-inducible factor 1. J Biol Chem 1994;269: 23757-23763.

13 Beckner ME, Chen X, An J, et al. Proteomic characterization of harvested pseudopodia with differential gel electrophoresis and specific antibodies. Lab Invest 2005;85:316-327.

14 Dringen R, Gebhardt R, Hamprecht B. Glycogen in astrocytes: possible function as lactate supply for neighboring cells. Brain Res 1993;623:208-214.

15 Pellerin L, Pellegri G, Bittar PG, et al. Evidence supporting the existence of an activity-dependent astrocyte-neuron lactate shuttle. Dev Neurosci 1998; 20:291-299.

16 Schurr A, Miller JJ, Payne RS, et al. An increase in lactate output by brain tissue serves to meet the energy needs of glutamate-activated neurons. J Neurosci 1999;19:34-39.

17 Voutsinos-Porche B, Bonvento G, Tanaka K, et al. Glial glutamate transporters mediate a functional metabolic crosstalk between neurons and astrocytes in the mouse developing cortex. Neuron 2003;37:275-286.

18 Kasischke KA, Vishwasrao HD, Fisher PJ, et al. Neural activity triggers neuronal oxidative metabolism followed by astrocytic glycolysis. Science 2004;305: 99-103.

19 Bernard-Helary K, Ardourel M, Magistretti P, et al. Stable transfection of cDNAs targeting specific steps of glycogen metabolism supports the existence of active gluconeogenesis in mouse cultured astrocytes. Glia 2002;37:379-382.

20 Dringen R, Schmoll D, Cesar M, et al. Incorporation of radioactivity from [14C]lactate into the glycogen of cultured mouse astroglial cells. Evidence for gluconeogenesis in brain cells. Biol Chem Hoppe Seyler 1993;374:343-347.

21 Hevor TK. Some aspects of carbohydrate metabolism in the brain. Biochimie 1994;76:111-120.

22 Hurel SJ, Rochford JJ, Borthwick AC, et al. Insulin action in cultured human myoblasts: contribution of different signalling pathways to regulation of glycogen synthesis. Biochem J 1996;320(Part 3):871-877.

23 Syed NA, Khandelwal RL. Reciprocal regulation of glycogen phosphorylase and glycogen synthase by insulin involving phosphatidylinositol-3 kinase and protein phosphatase-1 in HepG2 cells. Mol Cell Biochem 2000;211:123-136.

24 Sung CK, Choi WS, Scalia P. Insulin-stimulated glycogen synthesis in cultured hepatoma cells: differential effects of inhibitors of insulin signaling molecules. J Recept Signal Transduct Res 1998;18:243-263.

25 Cantley LC, Neel BG. New insights into tumor suppression: PTEN suppresses tumor formation by restraining the phosphoinositide 3-kinase/AKT pathway. Proc Natl Acad Sci USA 1999;96:4240-4245.

26 Fan X, Aalto Y, Sanko SG, et al. Genetic profile, PTEN mutation and therapeutic role of PTEN in glioblastomas. Int J Oncol 2002;21:1141-1150.

27 Zundel W, Schindler C, Haas-Kogan D, et al. Loss of PTEN facilitates HIF-1-mediated gene expression. Genes Dev 2000;14:391-396.

28 Sano T, Lin H, Chen X, et al. Differential expression of MMAC/PTEN in glioblastoma multiforme: relationship to localization and prognosis. Cancer Res 1999;59: 1820-1824.

29 Rose CR, Waxman SG, Ransom BR. Effects of glucose deprivation, chemical hypoxia, and simulated ischemia on $\mathrm{Na}+$ homeostasis in rat spinal cord astrocytes. J Neurosci 1998;18:3554-3562.

30 Swanson RA, Benington JH. Astrocyte glucose metabolism under normal and pathological conditions in vitro. Dev Neurosci 1996;18:515-521.

31 Bennett MC, Diamond DM, Stryker SL, et al. Cytochrome oxidase inhibition: a novel animal model of Alzheimer's disease. J Geriatr Psychiatry Neurol 1992;5:93-101.

32 Bennett MC, Mlady GW, Fleshner M, et al. Synergy between chronic corticosterone and sodium azide treatments in producing a spatial learning deficit and inhibiting cytochrome oxidase activity. Proc Natl Acad Sci USA 1996;93:1330-1334.

33 Bennett MC, Mlady GW, Kwon YH, et al. Chronic in vivo sodium azide infusion induces selective and stable inhibition of cytochrome $c$ oxidase. J Neurochem 1996;66:2606-2611.

34 Knyihar-Csillik E, Okuno E, Vecsei L. Effects of in vivo sodium azide administration on the immunohistochemical localization of kynurenine aminotransferase in the rat brain. Neuroscience 1999;94:269-277.

35 Berndt JD, Callaway NL, Gonzalez-Lima F. Effects of chronic sodium azide on brain and muscle cytochrome oxidase activity: a potential model to investigate environmental contributions to neurodegenerative diseases. J Toxicol Environ Health A 2001;63:67-77.

36 Cheng AM, Morrison SW, Yang DX, et al. Energy dependence of restitution in the gastric mucosa. Am J Physiol Cell Physiol 2001;281:C430-C438.

37 Barrett MJ, Alones V, Wang KX, et al. Mitochondriaderived oxidative stress induces a heat shock protein response. J Neurosci Res 2004;78:420-429.

38 Leal DB, Streher CA, Neu TN, et al. Characterization of NTPDase (NTPDase1; ecto-apyrase; ecto-diphosphohydrolase; CD39; EC 3.6.1.5) activity in human lymphocytes. Biochim Biophys Acta 2005;1721:9-15.

39 VanUffelen BE, Van der Zee J, de Koster BM, et al. Sodium azide enhances neutrophil migration and exocytosis: involvement of nitric oxide, cyclic GMP and calcium. Life Sci 1998;63:645-657. 
40 Colston VL, Wheeler TJ. Stimulation of cardiac glucose transport by inhibitors of oxidative phosphorylation. Life Sci 2001;69:2383-2398.

41 Dominguez JE, Graham JF, Cummins CJ, et al. Enzymes of glucose metabolism in cultured human gliomas: neoplasia is accompanied by altered hexokinase, phosphofructokinase, and glucose-6-phosphate dehydrogenase levels. Metab Brain Dis 1987;2:17-30.

42 Dringen R, Hamprecht B. Inhibition by 2-deoxyglucose and 1,5-gluconolactone of glycogen mobilization in astroglia-rich primary cultures. J Neurochem 1993;60: 1498-1504.

43 Gotoh J, Itoh Y, Kuang TY, et al. Negligible glucose-6phosphatase activity in cultured astroglia. J Neurochem 2000;74:1400-1408.

44 Oikonomakos NG, Zographos SE, Johnson LN, et al. The binding of 2-deoxy-D-glucose 6-phosphate to glycogen phosphorylase b: kinetic and crystallographic studies. J Mol Biol 1995;254:900-917.

45 Argaud D, Roth H, Wiernsperger N, et al. Metformin decreases gluconeogenesis by enhancing the pyruvate kinase flux in isolated rat hepatocytes. Eur J Biochem 1993;213:1341-1348.

46 Radziuk J, Zhang Z, Wiernsperger N, et al. Effects of metformin on lactate uptake and gluconeogenesis in the perfused rat liver. Diabetes 1997;46:1406-1413.

47 Powis G, Bonjouklian R, Berggren MM, et al. Wortmannin, a potent and selective inhibitor of phosphatidylinositol-3-kinase. Cancer Res 1994;54:2419-2423.

48 He TC, Zhou S, da Costa LT, et al. A simplified system for generating recombinant adenoviruses. Proc Natl Acad Sci USA 1998;95:2509-2514.

49 Abounader R, Lal B, Luddy $\mathrm{C}$, et al. In vivo targeting of $\mathrm{SF} / \mathrm{HGF}$ and c-met expression via U1snRNA/ribozymes inhibits glioma growth and angiogenesis and promotes apoptosis. FASEB J 2002;16:108-110.

50 Yan SF, Lu J, Zou YS, et al. Hypoxia-associated induction of early growth response-1 gene expression. J Biol Chem 1999;274:15030-15040.

51 Nishi H, Nishi KH, Johnson AC. Early growth response-1 gene mediates up-regulation of epidermal growth factor receptor expression during hypoxia. Cancer Res 2002;62:827-834.

52 Gess $\mathrm{B}$, Wolf $\mathrm{K}$, Pfeifer $\mathrm{M}$, et al. In vivo carbon monoxide exposure and hypoxic hypoxia stimulate immediate early gene expression. Pflugers Arch 1997; 434:568-574.

53 Muller JM, Krauss B, Kaltschmidt C, et al. Hypoxia induces c-fos transcription via a mitogen-activated protein kinase-dependent pathway. J Biol Chem 1997;272:23435-23439.

54 Premkumar DR, Adhikary G, Overholt JL, et al. Intracellular pathways linking hypoxia to activation of c-fos and AP-1. Adv Exp Med Biol 2000;475:101-109.

55 Turcotte ML, Parliament M, Franko A, et al. Variation in mitochondrial function in hypoxia-sensitive and hypoxia-tolerant human glioma cells. Br J Cancer 2002;86:619-624.

56 Ermonian RP, Furniss CS, Lamborn KR, et al. Dysregulation of PTEN and protein kinase $B$ is associated with glioma histology and patient survival. Clin Cancer Res 2002;8:1100-1106.

57 Haas-Kogan DA, Prados MD, Tihan T, et al. Epidermal growth factor receptor, protein kinase B/Akt, and glioma response to erlotinib. J Natl Cancer Inst 2005;97:880-887.
58 Alvarez-Tejado M, Naranjo-Suarez S, Jimenez C, et al. Hypoxia induces the activation of the phosphatidylinositol 3-kinase/Akt cell survival pathway in PC12 cells: protective role in apoptosis. J Biol Chem 2001;276:22368-22374.

59 Beitner-Johnson D, Rust RT, Hsieh TC, et al. Hypoxia activates Akt and induces phosphorylation of GSK-3 in PC12 cells. Cell Signal 2001;13:23-27.

60 Scandurro AB, Weldon CW, Figueroa YG, et al. Gene microarray analysis reveals a novel hypoxia signal transduction pathway in human hepatocellular carcinoma cells. Int J Oncol 2001;19:129-135.

61 Roh MS, Eom TY, Zmijewska AA, et al. Hypoxia activates glycogen synthase kinase-3 in mouse brain in vivo: protection by mood stabilizers and imipramine. Biol Psychiatr 2005;57:278-286.

62 Krylova O, Messenger MJ, Salinas PC. Dishevelled-1 regulates microtubule stability: a new function mediated by glycogen synthase kinase-3beta. J Cell Biol 2000;151:83-94.

63 Papkoff J, Aikawa M. WNT-1 and HGF regulate GSK3 beta activity and beta-catenin signaling in mammary epithelial cells. Biochem Biophys Res Commun 1998;247:851-858.

64 Sutherland C, Cohen P. The $\alpha$-isoform of glycogen synthase kinase-3 from rabbit skeletal muscle is inactivated by p70 S6 kinase or MAP kinase-activated protein kinase-1 in vitro. FEBS Lett 1994;338:37-42.

65 Malik RK, Roe MW, Blackshear PJ. Epidermal growth factor and other mitogens induce binding of a protein complex to the c-fos serum response element in human astrocytoma and other cells. J Biol Chem 1991;266: 8576-8582.

66 Selinfreund RH, Barger SW, Pledger WJ, et al. Neurotrophic protein S100 beta stimulates glial cell proliferation. Proc Natl Acad Sci USA 1991;88: 3554-3558.

67 Abounader R, Ranganathan S, Kim BY, et al. Signaling pathways in the induction of c-met receptor expression by its ligand scatter factor/hepatocyte growth factor in human glioblastoma. J Neurochem 2001;76: 1497-1508.

68 Kaufmann K, Thiel G. Epidermal growth factor and platelet-derived growth factor induce expression of Egr-1, a zinc finger transcription factor, in human malignant glioma cells. J Neurol Sci 2001;189:83-91.

69 Meyer RG, Kupper JH, Kandolf R, et al. Early growth response-1 gene (Egr-1) promoter induction by ionizing radiation in U87 malignant glioma cells in vitro. Eur J Biochem 2002;269:337-346.

70 Liu C, Yao J, Mercola D, et al. The transcription factor EGR-1 directly transactivates the fibronectin gene and enhances attachment of human glioblastoma cell line U251. J Biol Chem 2000;275:20315-20323.

71 Papaconstantinou J, Colowick SP. The role of glycolysis in the growth of tumor cells. I. Effects of oxamic acid on the metabolism of Ehrlich ascites tumor cells in vitro. J Biol Chem 1961;236:278-284.

$72 \mathrm{Liu} \mathrm{H}, \mathrm{Hu}$ YP, Savaraj N, et al. Hypersensitization of tumor cells to glycolytic inhibitors. Biochemistry 2001;40:5542-5547.

73 Liu H, Savaraj N, Priebe W, et al. Hypoxia increases tumor cell sensitivity to glycolytic inhibitors: a strategy for solid tumor therapy (Model C). Biochem Pharmacol 2002;64:1745-1751. 